\title{
Streptococcal pyoderma of the penis following fellatio
}

\author{
LEWIS $M$. DRUSIN, BARRY $M$. WILKES, AND ROGER D. GINGRICH \\ From the Departments of Public Health and Medicine, New York Hospital, \\ Cornell Medical Center, New York
}

The occurrence of gonococcal pharyngitis and its association with the practice of fellatio in both heterosexual females and homosexual males has been well described in the literature (Fiumara, Wise, and Many, 1967; Wiesner, Tronca, Bonin, Pedersen, and Holmes, 1973; Owen and Hill, 1972). This report presents a case of streptococcal pyoderma of the penis as another important complication of fellatio.

\section{Case report}

A 28-year-old homosexual male was seen in the New York Hospital Out-patients Department complaining of a painful swelling of the glans penis for 7 days. His only sexual experience in recent months had been one episode of fellatio performed by an anonymous male 10 days before his visit to the clinic. On the day after the onset of symptoms, he noticed a weeping red rash which progressed to involve the entire coronal sulcus of the penis. He denied urethral discharge or dysuria. His past history included urethral gonorrhoea treated with penicillin 2 years earlier and anal condylomata acuminata which had been fulgurated during a hospital admission 8 months earlier.

\section{Examination}

He was a well-developed, well-nourished young man in no distress. His vital signs and temperature were normal. The penis was circumcised. The testicles were non-tender, and the inguinal lymph nodes not enlarged. A moist erythematous lesion with a purulent yellow exudate completely involved the coronal sulcus (Figure). There was no discharge from the urethral meatus.

Bacterial cultures were made from the purulent material from the coronal sulcus, and from the urethral meatus.

\section{Treatment}

Oral tetracycline $1.5 \mathrm{~g}$. initially was followed by $0.5 \mathrm{~g}$. every $6 \mathrm{hrs}$. After 3 days the lesions were not improved.

Received for publication May 21, 1974

Address for reprints: L. M. Drusin, M.D., Assistant Professor of Public Health, Cornell Medical Center, 525 East 68th Street, New York, N.Y. 10021, U.S.A.

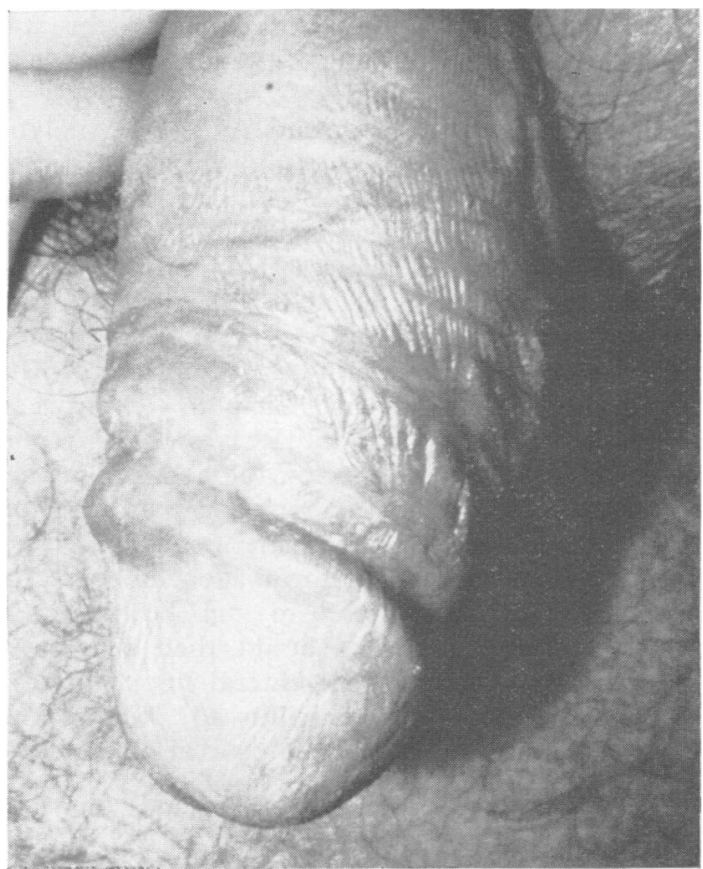

FIGURE Erythematous lesion with purulent exudate on the coronal sulcus of the penis

\section{Diagnosis}

Material from the urethral meatus failed to grow Neisseria gonorrhoea, but the culture of the purulent exudate from the coronal sulcus yielded a group A beta-haemolytic streptococcus, confirmed by Lancefield classification. The organism was resistant to tetracycline, and this medication was therefore replaced by oral penicillin $0.5 \mathrm{~g}$. four times daily for 10 days.

Result

One month later the penile lesions had healed completely. The serum VDRL and FTA-ABS were both negative.

\section{Discussion}

The coronal sulcus is a frequent site of injury to the penis following fellatio. Usually, the patient describes 
a small abrasion which progresses to a painful ulcer with a purulent exudate. Bacterial cultures reveal normal mouth flora such as Streptococcus viridans and Neisseria flava. These penile lesions heal promptly after the local application of a topical antibacterial preparation two or three times daily for several days.

In this patient, bacterial cultures from the coronal sulcus yielded only a group A beta-haemolytic Streptococcus. Assuming that his sexual partner had a streptococcal pharyngitis, it would have been interesting to have recovered the organism and by using T-typing to have compared the two streptococcal strains. This might have confirmed their epidemiological association. Unfortunately, this was impossible because the patient's sexual contact was anonymous.

Skin lesions caused by group A beta-haemolytic Streptococcus have been associated with both septicaemia (Hable, Horstmeier, Wold, and Washington, 1973) and nephritis (Wannamaker, 1970; Dillon, 1967; Dillon and Reeves, 1974). Although the streptococcal strains associated with nephritis can be further characterized by M-typing (Johnson and Stollerman, 1969), precipitin tests on the organism isolated from this patient failed to identify an M-serotype. Since Dillon and Reeves (1974) report that streptococcal skin infection alone with neither respiratory infection nor colonization may 'precipitate post-streptococcal acute glomerulonephritis', it is extremely important to perform adequate bacterial cultures so that the organism can be positively identified. These patients should then be treated with either a long-acting parenteral penicillin or a 10-day course of oral penicillin to prevent this dangerous complication of streptococcal disease.

\section{Summary}

Gonococcal pharyngitis has been correlated with fellatio in both heterosexual females and homosexual males. This report describes another complication of fellatio, group A beta-haemolytic streptococcal pyo- derma on the penis after exposure to a male who probably had pharyngitis. The erythematous, purulent lesions should be cultured. After the organism has been identified, adequate treatment with either a long-acting parenteral penicillin or a 10-day course of oral penicillin is important in order to prevent the possible life-threatening complication of poststreptococcal glomerulonephritis.

\section{References}

Dillon, H. C., Jr. (1967) Ann. Rev. Med., 18, 207

and Reeves, M. S. A. (1974) Amer. F. Med., 56, 333

Fiumara, N. J., Wise, H. M., and MaNy, M. (1967) New Engl. F. Med., 276, 1248

Hable, K. A., Horstmeier, C., Wold, A. D., and Washington, J. A. II (1973) Mayo Clin. Proc., 48, 336

Johnson, J. C., and Stollerman, G. H. (1969) Ann. Rev. Med., 20, 315

Owen, R. L. and Hill, J. L. (1972) F. Amer. med. Ass., 220, 1315

WannamakeR, L. W. (1970) New Engl. f. Med., 282, 23, 78

Wiesner, P. J., Tronca, E., Bonin, P., Pedersen, A. H. B., and Holmes, K. K. (1973) Ibid., 288, 181

Pyodermite streptococcique du pénis après fellatio

SOMMAIRE

La pharyngite gonococcique a été rapportée aux pratiques de fellatio, aussi bien chez les femmes hétéro sexuelles que chez les hommes homosexuels. Le présent rapport décrit une autre complication du fellatio, consistant en une pyodermite streptococcique du pénis à streptocoque beta-hémolytique du groupe $A$, après contact avec un homme atteint probablement de pharyngite. Un prélèvement des lésions érythémateuses et purulentes doit être mis en culture. Après identification de l'organisme, il est important d'appliquer un traitement approprié, soit par une pénicilline parentérale de longue action, soit par une série de 10 jours de pénicilline orale, afin de prévenir la complication qui serait la glomérulonéphrite poststreptococcique et qui pourrait mettre la vie du malade en danger. 